Article

\title{
Genetic Differences among Established Populations of Aromia bungii (Faldermann, 1835) (Coleoptera: Cerambycidae) in Japan: Suggestion of Multiple Introductions
}

\author{
Shigeaki Tamura *(D) and Etsuko Shoda-Kagaya
}

Citation: Tamura, S.; Shoda-Kagaya, E. Genetic Differences among Established Populations of Aromia bungii (Faldermann, 1835)

(Coleoptera: Cerambycidae) in Japan: Suggestion of Multiple Introductions. Insects 2022, 13, 217. https:// doi.org/10.3390/insects13020217

Academic Editor: $\mathrm{Hu} \mathrm{Li}$

Received: 21 January 2022

Accepted: 14 February 2022

Published: 21 February 2022

Publisher's Note: MDPI stays neutral with regard to jurisdictional claims in published maps and institutional affiliations.

Copyright: (C) 2022 by the authors. Licensee MDPI, Basel, Switzerland. This article is an open access article distributed under the terms and conditions of the Creative Commons Attribution (CC BY) license (https:// creativecommons.org/licenses/by/ $4.0 /)$.
Department of Forest Entomology, Forestry and Forest Products Research Institute, Forest Research and Management Organization, Matsunosato 1, Tsukuba 305-8687, Japan; eteshoda@affrc.go.jp

* Correspondence: tamus@affrc.go.jp; Tel.: +81-(0)29-829-8251

Simple Summary: The red-necked longhorn beetle, Aromia bungii, is a pest that damages Rosaceae trees such as peach and cherry. This beetle has been introduced into Japan and expanded its distribution rapidly during the last decade. Currently, Japanese populations of A. bungii are widely distributed in six non-contiguous regions. The DNA sequences of partial mitochondrial DNA were analysed in Japanese populations of $A$. bungii in order to discuss whether multiple introductions or human-mediated long-distance dispersal have contributed to the non-contiguous distribution of $A$. bungii. Seven haplotypes were detected in Japanese populations. Haplotype composition differed among the six non-contiguous regions. These results suggest that multiple introductions have contributed to the non-contiguous distribution of A. bungii in Japanese populations.

\begin{abstract}
Aromia bungii (Faldermann) (Coleoptera: Cerambycidae) is an invasive pest, damaging Rosaceae trees (particularly Prunus) in Japan and Europe. The establishment of this beetle in Japan was first detected in 2012, and subsequently, it has rapidly expanded its distribution. Currently, Japanese populations of $A$. bungii are widely distributed in six non-contiguous regions. In this study, we compared the nucleotide sequences of mitochondrial cytochrome oxidase subunit 1 of the populations in these six regions in Japan to examine whether multiple introductions or humanmediated long-distance dispersal have contributed to the non-contiguous distribution of $A$. bungii. Seven haplotypes were detected from Japanese populations, and one of these was identical to a sequence deposited from China. One to two haplotypes were detected in each region, suggesting a genetic bottleneck. Detected haplotypes differed between introduced regions, although two regions shared a single haplotype. These results suggest that multiple independent introductions of $A$. bungii have contributed to its non-contiguous distribution in Japan. Quarantine measures for wood-packing materials in trade need to be strengthened to prevent the establishment of further populations of $A$. bungii.
\end{abstract}

Keywords: genetic analyses; invasive pests; mitochondrial DNA; red-necked longicorn beetle; Rosaceae; wood-boring insect

\section{Introduction}

The red-necked longicorn beetle, Aromia bungii (Faldermann, 1835) (Coleoptera: Cerambycidae), is an invasive wood-boring pest, which has been recently introduced into Germany, Italy, and Japan from countries within its original range, such as China, Korea, Mongolia, and Vietnam [1]. The hosts of A. bungii are primarily Rosaceae trees, particularly Prunus species [1], and the larvae of $A$. bungii often severely damage host trees by feeding on the inner bark and cambium, and by boring into the xylem of the trees. Therefore, they cause economic losses by decreasing the yields of Rosaceae fruit crops, such as peaches and apricots, both in their countries of origin and where they have been introduced [1-3]. 
Additionally, ecosystem disturbance by A. bungii is a concern in Japan because A. bungii can grow in the logs of Rosaceae trees in natural forests [4].

In Japan, the establishment of A. bungii was first detected in 2012 [5]. By 2019, A. bungii was widely distributed in six non-contiguous regions of Japan: northern Kanto, southern Saitama, western Tokyo, southern Tokai, western Kansai, and northern Tokushima [6,7] (Figure 1). The establishment of this beetle was first detected in southern Tokai in 2012, southern Saitama in 2013, and the other four regions in 2015 [7]. In all of these regions, $A$. bungii was first detected because of damage caused to ornamental cherry trees (e.g., Cerasus $\times$ yedoensis 'Somei-yoshino') planted in urban areas [5,8-10]. In northern Tokushima, peach (Prunus persica) and Japanese apricot (P. mume) trees in orchards were also damaged by $A$. bungii [11]. Distributions of $A$. bungii have gradually expanded in all introduced regions [7].

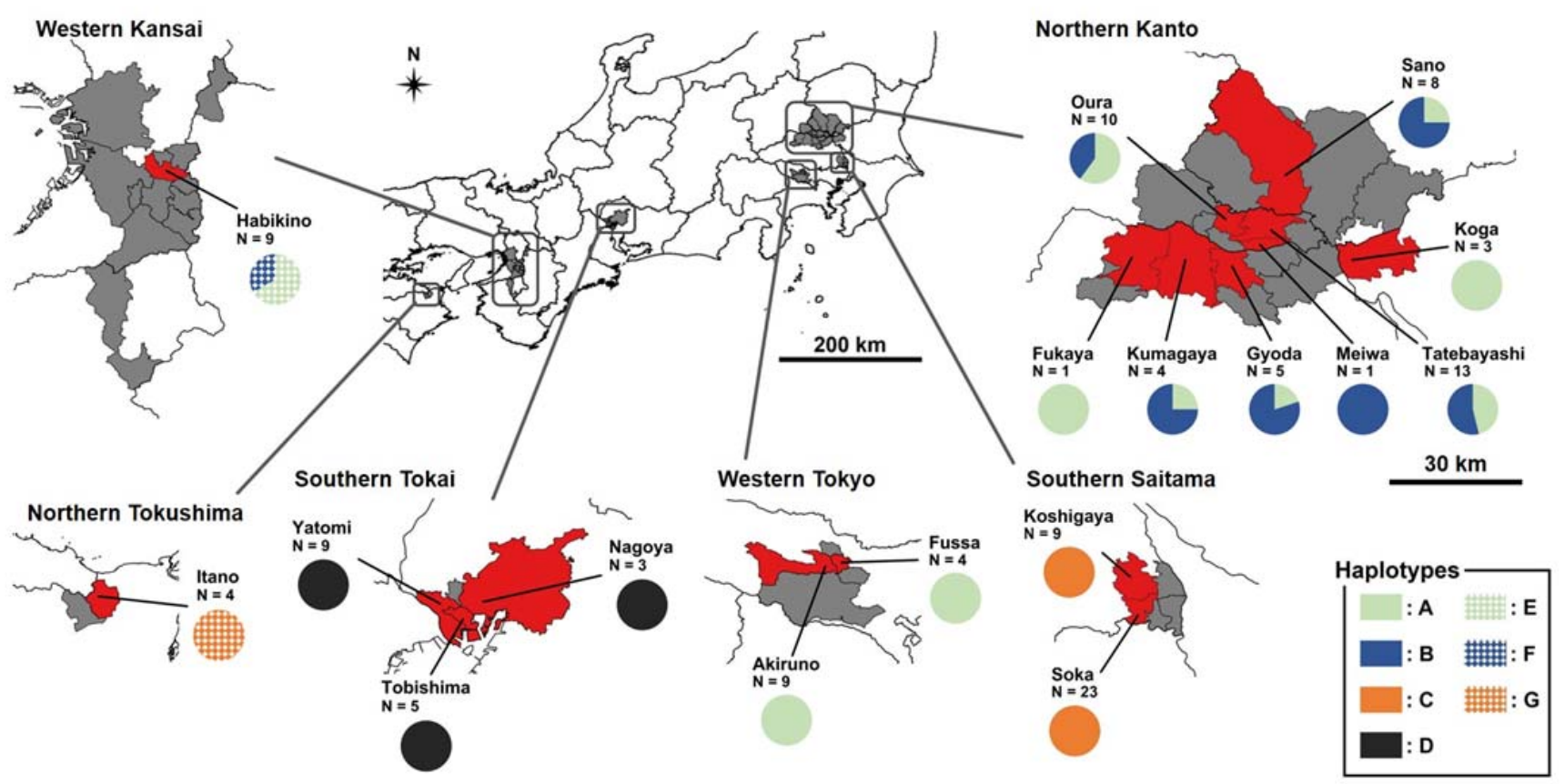

Figure 1. The distribution of Aromia bungii and its haplotypes based on mitochondrial CO1 sequences in Japan. Red shading indicates municipalities where individuals were sampled, and grey shading indicates municipalities where other populations of $A$. bungii were recorded as being established in 2019. Haplotype compositions of the studied municipalities have been combined for multiple study sites. $\mathrm{N}$ indicates the number of analysed individuals of $A$. bungii. All enlarged maps have the same scale. Maps were drawn based on those produced by the Digital National Land Information (administrative division data) and the Ministry of Land, Infrastructure, Transport, and Tourism Japan: https:/ / nlftp.mlit.go.jp/ksj/index.html (accessed on 6 June 2021).

Exotic wood-boring pests are often introduced in wood-packing materials, and their invasion has increased with increasing trade [12]. Recently, multiple introductions of exotic wood-boring insects have been reported, which are thought to have been introduced in wood-packing materials [13-17]. Multiple introductions may have contributed to the extremely wide distribution of the Asian long-horned beetle (Anoplophora glabripennis) in Europe and North America [15,16]. Additionally, A. bungii may have been introduced via the presence of its larval and pupal stages in wood-packing materials [1]. For example, individuals of $A$. bungii have been intercepted on wood-packing materials in Washington State in the United States of America, Baden-Württemberg in Germany, and in the United Kingdom [18]. The non-contiguous distribution of A. bungii in Japan suggests multiple independent introductions in each region. However, Iwata [6] pointed out the possibility that the non-contiguous distribution of $A$. bungii was formed by human-mediated longdistance dispersal, caused by the species 'hitchhiking' on vehicles. Understanding whether 
multiple introductions or human-mediated long-distance dispersal has contributed to the distribution of $A$. bungii could be useful for the management of this beetle.

In this study, we compared nucleotide sequences of the mitochondrial cytochrome oxidase subunit 1 (CO1) region of $A$. bungii populations in Japan to examine whether multiple introductions and establishments or human-mediated long-distance dispersal has contributed to the non-contiguous distribution of $A$. bungii. If multiple independent introductions of $A$. bungii occurred in Japan, then there would be genetic differences between invaded regions. However, if there was long-distance dispersal between regions, then populations would be genetically similar between invaded regions.

\section{Materials and Methods}

We collected 4-45 individuals of $A$. bungii from 1 to 14 sites in all six introduced regions in 2015-2019, resulting in a total of 120 individuals (101 adults, 18 larvae, and 1 pupa) being collected from 37 sites in Japan (Table 1, Supplemental Table S1, Figure 2). Of the 101 adults, 85 were collected in the field and 16 emerged from the logs of damaged trees transported to the laboratory. All larvae and the single pupa were collected by cutting trees or peeling bark. The adults collected in northern Kanto, southern Saitama, western Tokyo, and northern Tokushima were frozen immediately after transporting them to our laboratory. The adults collected in Southern Tokai and western Kansai were fixed in 99.5\% ethanol or $98 \%$ propylene glycol immediately after collection. All larvae and the single pupa were fixed in $99.5 \%$ ethanol immediately after bringing them to our laboratory. We preserved all samples at $-30{ }^{\circ} \mathrm{C}$ in freezers until DNA extraction. We did not notice a difference in the morphology of collected adults, such as body size and coloration, among invaded regions.

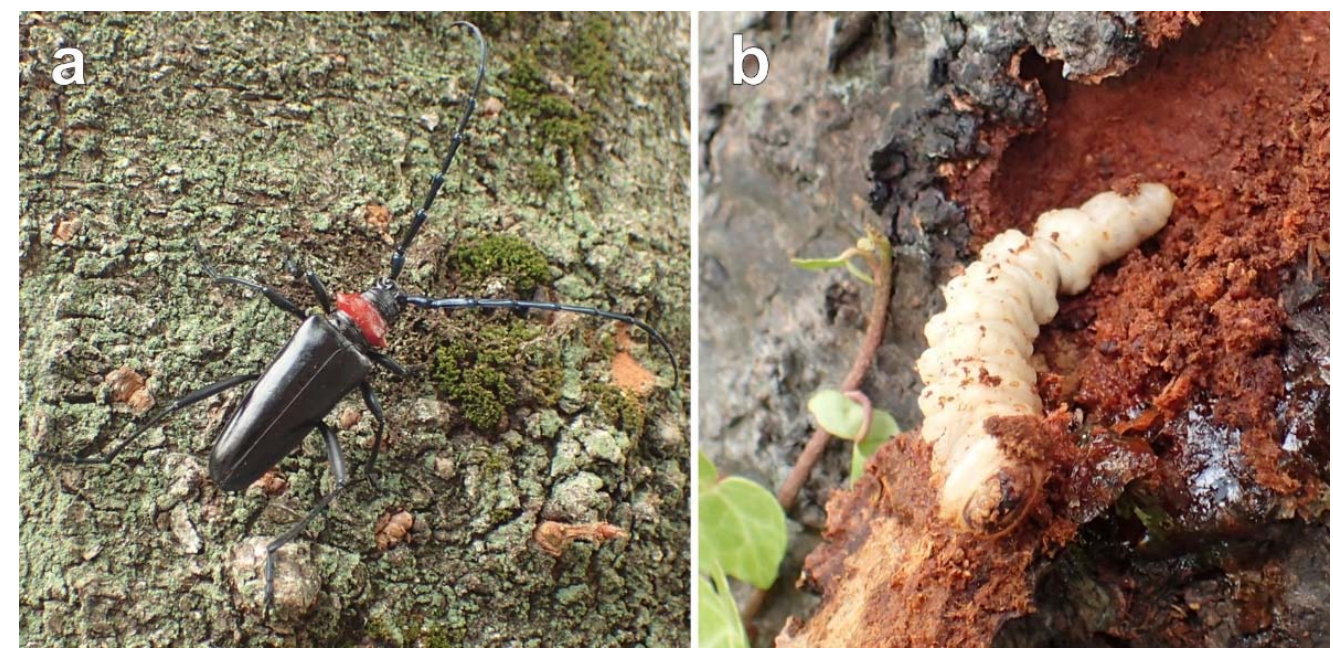

Figure 2. Photos of collected individuals of Aromia bungii in the field. (a) An adult female collected on the bark of a cherry tree in Tatebayashi City, Gunma Prefecture, on 28 June 2018. (b) A larva collected by peeling bark on a cherry tree in Fussa City, Tokyo Metropolis, on 22 May 2019. 
Table 1. Sampling information and haplotype compositions of Aromia bungii.

\begin{tabular}{|c|c|c|c|c|c|c|c|c|c|c|c|c|c|}
\hline \multirow{2}{*}{ Introduced Region } & \multirow{2}{*}{ Prefecture } & \multirow{2}{*}{ Municipality } & \multirow{2}{*}{ Site } & \multirow{2}{*}{ Longitude } & \multirow{2}{*}{ Latitude } & \multirow{2}{*}{ Year } & \multicolumn{7}{|c|}{ Haplotype Composition } \\
\hline & & & & & & & A & B & $\mathrm{C}$ & $\mathbf{D}$ & $\mathbf{E}$ & F & G \\
\hline \multirow[t]{13}{*}{ Northern Kanto } & \multirow[t]{7}{*}{ Gunma } & \multirow[t]{3}{*}{ Tatebayashi } & GTa1 & $36^{\circ} 14.6^{\prime} \mathrm{N}$ & $139^{\circ} 30.8^{\prime} \mathrm{E}$ & 2018 & 3 & 0 & 0 & 0 & 0 & 0 & 0 \\
\hline & & & GTa2 & $36^{\circ} 14.5^{\prime} \mathrm{N}$ & $139^{\circ} 32.8^{\prime} \mathrm{E}$ & 2018 & 1 & 1 & 0 & 0 & 0 & 0 & 0 \\
\hline & & & GTa3 & $36^{\circ} 13.7^{\prime} \mathrm{N}$ & $139^{\circ} 32.0^{\prime} \mathrm{E}$ & 2018 & 2 & 6 & 0 & 0 & 0 & 0 & 0 \\
\hline & & \multirow[t]{3}{*}{ Oura } & GOu1 & $36^{\circ} 14.3^{\prime} \mathrm{N}$ & $139^{\circ} 29.5^{\prime} \mathrm{E}$ & 2019 & 3 & 2 & 0 & 0 & 0 & 0 & 0 \\
\hline & & & GOu2 & $36^{\circ} 15.2^{\prime} \mathrm{N}$ & $139^{\circ} 28.3^{\prime} \mathrm{E}$ & 2019 & 2 & 0 & 0 & 0 & 0 & 0 & 0 \\
\hline & & & GOu3 & $36^{\circ} 16.2^{\prime} \mathrm{N}$ & $139^{\circ} 26.9^{\prime} \mathrm{E}$ & 2019 & 1 & 2 & 0 & 0 & 0 & 0 & 0 \\
\hline & & \multirow{3}{*}{$\begin{array}{c}\text { Meiwa } \\
\text { Sano }\end{array}$} & GMe1 & $36^{\circ} 12.5^{\prime} \mathrm{N}$ & $139^{\circ} 31.8^{\prime} \mathrm{E}$ & 2018 & 0 & 1 & 0 & 0 & 0 & 0 & 0 \\
\hline & \multirow[t]{2}{*}{ Tochigi } & & \multirow[t]{2}{*}{ TSa1 } & \multirow[t]{2}{*}{$36^{\circ} 17.0^{\prime} \mathrm{N}$} & \multirow{2}{*}{$139^{\circ} 32.8^{\prime} \mathrm{E}$} & 2018 & 0 & 1 & 0 & 0 & 0 & 0 & 0 \\
\hline & & & & & & 2019 & 2 & 5 & 0 & 0 & 0 & 0 & 0 \\
\hline & Ibaraki & Koga & IKo1 & $36^{\circ} 10.8^{\prime} \mathrm{N}$ & $139^{\circ} 42.1^{\prime} \mathrm{E}$ & 2019 & 3 & 0 & 0 & 0 & 0 & 0 & 0 \\
\hline & Saitama & Fukaya & SFu1 & $36^{\circ} 10.6^{\prime} \mathrm{N}$ & $139^{\circ} 13.6^{\prime} \mathrm{E}$ & 2019 & 1 & 0 & 0 & 0 & 0 & 0 & 0 \\
\hline & & Kumagaya & SKu1 & $36^{\circ} 09.7^{\prime} \mathrm{N}$ & $139^{\circ} 24.7^{\prime} \mathrm{E}$ & 2019 & 1 & 3 & 0 & 0 & 0 & 0 & 0 \\
\hline & & Gyoda & SGy1 & $36^{\circ} 10.9^{\prime} \mathrm{N}$ & $139^{\circ} 28.4^{\prime} \mathrm{E}$ & 2019 & 1 & 4 & 0 & 0 & 0 & 0 & 0 \\
\hline \multirow[t]{14}{*}{ Southern Saitama } & \multirow[t]{14}{*}{ Saitama } & \multirow[t]{12}{*}{ Soka } & SSo1 & $35^{\circ} 50.4^{\prime} \mathrm{N}$ & $139^{\circ} 47.7^{\prime} \mathrm{E}$ & 2017 & 0 & 0 & 2 & 0 & 0 & 0 & 0 \\
\hline & & & SSo2 & $35^{\circ} 50.2^{\prime} \mathrm{N}$ & $139^{\circ} 49.1^{\prime} \mathrm{E}$ & 2018 & 0 & 0 & 3 & 0 & 0 & 0 & 0 \\
\hline & & & SSo3 & $35^{\circ} 50.7^{\prime} \mathrm{N}$ & $139^{\circ} 49.7^{\prime} \mathrm{E}$ & 2018 & 0 & 0 & 2 & 0 & 0 & 0 & 0 \\
\hline & & & SSo4 & $35^{\circ} 50.8^{\prime} \mathrm{N}$ & $139^{\circ} 49.8^{\prime} \mathrm{E}$ & 2018 & 0 & 0 & 1 & 0 & 0 & 0 & 0 \\
\hline & & & SSo5 & $35^{\circ} 50.8^{\prime} \mathrm{N}$ & $139^{\circ} 49.5^{\prime} \mathrm{E}$ & 2019 & 0 & 0 & 3 & 0 & 0 & 0 & 0 \\
\hline & & & SSo6 & $35^{\circ} 51.6^{\prime} \mathrm{N}$ & $139^{\circ} 48.9^{\prime} \mathrm{E}$ & 2019 & 0 & 0 & 2 & 0 & 0 & 0 & 0 \\
\hline & & & SSo7 & $35^{\circ} 50.3^{\prime} \mathrm{N}$ & $139^{\circ} 49.6^{\prime} \mathrm{E}$ & 2019 & 0 & 0 & 1 & 0 & 0 & 0 & 0 \\
\hline & & & SSo8 & $35^{\circ} 50.7^{\prime} \mathrm{N}$ & $139^{\circ} 49.5^{\prime} \mathrm{E}$ & 2019 & 0 & 0 & 1 & 0 & 0 & 0 & 0 \\
\hline & & & SSo9 & $35^{\circ} 51.0^{\prime} \mathrm{N}$ & $139^{\circ} 49.3^{\prime} \mathrm{E}$ & 2019 & 0 & 0 & 3 & 0 & 0 & 0 & 0 \\
\hline & & & SSo10 & $35^{\circ} 50.8^{\prime} \mathrm{N}$ & $139^{\circ} 49.7^{\prime} \mathrm{E}$ & 2019 & 0 & 0 & 2 & 0 & 0 & 0 & 0 \\
\hline & & & SSo11 & $35^{\circ} 51.5^{\prime} \mathrm{N}$ & $139^{\circ} 50.1^{\prime} \mathrm{E}$ & 2019 & 0 & 0 & 1 & 0 & 0 & 0 & 0 \\
\hline & & & SSo12 & $35^{\circ} 51.6^{\prime} \mathrm{N}$ & $139^{\circ} 49.6^{\prime} \mathrm{E}$ & 2019 & 0 & 0 & 2 & 0 & 0 & 0 & 0 \\
\hline & & \multirow{2}{*}{ Koshigaya } & Sko1 & $35^{\circ} 52.3^{\prime} \mathrm{N}$ & $139^{\circ} 48.3^{\prime} \mathrm{E}$ & 2019 & 0 & 0 & 8 & 0 & 0 & 0 & 0 \\
\hline & & & Sko2 & $35^{\circ} 53.3^{\prime} \mathrm{N}$ & $139^{\circ} 48.0^{\prime} \mathrm{E}$ & 2019 & 0 & 0 & 1 & 0 & 0 & 0 & 0 \\
\hline Western Tokyo & Tokyo & Akiruno & TAk1 & $35^{\circ} 43.5^{\prime} \mathrm{N}$ & $139^{\circ} 19.5^{\prime} \mathrm{E}$ & 2017 & 4 & 0 & 0 & 0 & 0 & 0 & 0 \\
\hline & & & & & & 2018 & 5 & 0 & 0 & 0 & 0 & 0 & 0 \\
\hline & & Fussa & TFu1 & $35^{\circ} 44.1^{\prime} \mathrm{N}$ & $139^{\circ} 19.2^{\prime} \mathrm{E}$ & 2019 & 4 & 0 & 0 & 0 & 0 & 0 & 0 \\
\hline Southern Tokai & Aichi & Tobishima & ATo1 & $35^{\circ} 04.9^{\prime} \mathrm{N}$ & $136^{\circ} 47.2^{\prime} \mathrm{E}$ & 2015 & 0 & 0 & 0 & 1 & 0 & 0 & 0 \\
\hline & & & ATo 2 & $35^{\circ} 05.1^{\prime} \mathrm{N}$ & $136^{\circ} 46.9^{\prime} \mathrm{E}$ & 2017 & 0 & 0 & 0 & 1 & 0 & 0 & 0 \\
\hline & & & ATo3 & NA & NA & 2019 & 0 & 0 & 0 & 3 & 0 & 0 & 0 \\
\hline & & Yatomi & AYa1 & $35^{\circ} 06.3^{\prime} \mathrm{N}$ & $136^{\circ} 44.9^{\prime} \mathrm{E}$ & 2019 & 0 & 0 & 0 & 5 & 0 & 0 & 0 \\
\hline & & & AYa2 & $35^{\circ} 04.8^{\prime} \mathrm{N}$ & $136^{\circ} 45.1^{\prime} \mathrm{E}$ & 2019 & 0 & 0 & 0 & 4 & 0 & 0 & 0 \\
\hline & & Nagoya & ANa1 & $35^{\circ} 07.1^{\prime} \mathrm{N}$ & $136^{\circ} 52.3^{\prime} \mathrm{E}$ & 2019 & 0 & 0 & 0 & 3 & 0 & 0 & 0 \\
\hline Western Kansai & Osaka & Habikino & OHa1 & $34^{\circ} 32.1^{\prime} \mathrm{N}$ & $135^{\circ} 35.9^{\prime} \mathrm{E}$ & 2017 & 0 & 0 & 0 & 0 & 3 & 0 & 0 \\
\hline & & & & & & 2019 & 0 & 0 & 0 & 0 & 2 & 1 & 0 \\
\hline & & & $\mathrm{OHa} 2$ & $34^{\circ} 32.3^{\prime} \mathrm{N}$ & $135^{\circ} 35.5^{\prime} \mathrm{E}$ & 2019 & 0 & 0 & 0 & 0 & 1 & 2 & 0 \\
\hline Northern Tokushima & Tokushima & Itano & TIt1 & NA & NA & 2017 & 0 & 0 & 0 & 0 & 0 & 0 & 4 \\
\hline
\end{tabular}

NA indicates that geographical information for sampling sites is not provided, in order to protect the privacy of the responsible landowners/organizations.

We sequenced two sections of the mitochondrial DNA CO1 regions (612 and 762 bp) of all collected individuals. In our preliminary analysis, we found only a few nucleotide substitutions in the 612-bp section. Thus, we additionally analyzed the 762-bp section. We used PrepMan Ultra Sample Preparation Reagent (Applied Biosystems, Foster City, CA, USA) to extract DNA from muscle tissues. Dried tissues were added to $75 \mu \mathrm{L}$ PrepMan liquid in $1.5 \mathrm{~mL}$ tubes and then heated at $100{ }^{\circ} \mathrm{C}$ for $10 \mathrm{~min}$. Then, we centrifuged the tubes at $14,000 \mathrm{rpm}(17,800 \times g)$ for $3 \mathrm{~min}$ via a centrifuge $(\mathrm{mx}-301$, Tomy Seiko, Japan), and diluted the supernatant liquid tenfold with MilliQ water. MilliQ water was produced by a Synergy UV Water Purification System (Millipore, Burlington, MA, USA). We used the diluted liquid as extracted DNA for polymerase chain reaction (PCR) without measuring the quality of extracted DNA by spectrophotometer.

We mixed PCR reagents for each reaction: $0.13 \mu \mathrm{L}$ of TaKaRa Ex Taq (TaKaRa Bio, Japan) or TaKaRa Ex Taq Hot Start ver. (TaKaRa Bio, Japan); $2 \mu \mathrm{L}$ of $10 \times$ Ex Taq Buffer; $1.6 \mu \mathrm{L}$ of dNTP mixture; $2 \mu \mathrm{L}$ of each primer $(100 \mu \mathrm{M} / \mathrm{L})$; and $13 \mu \mathrm{L}$ of MilliQ water. We used two primer pairs: LCO1490 (5'-GGTCAACAAATCATAAAGATATTGG-3') and HCO2198 (5'-TAAACTTCAGGGTGACCAAAAAATCA-3') [19] for the shorter section, and CO1-Croz (5'-CAACATTTATTTTGATTTTTTGGTCA-3) [20] and tRNA ${ }^{\text {Leu }}$-R (5'-GGGGTTTAAATCCATTGCAC-3') for the longer section. The primer tRNA ${ }^{\text {Leu }}$-R was the reverse sequence of tRNA ${ }^{\mathrm{Leu}_{-}} \mathrm{F}$, and was designed by Kawai et al. [21]. We added $17 \mu \mathrm{L}$ of mixed PCR regents and $0.8 \mu \mathrm{L}$ of extracted DNA to $0.2 \mathrm{~mL}$ tubes. We performed PCR amplification of the profile as follows: 30 cycles of $94{ }^{\circ} \mathrm{C}$ for $30 \mathrm{~s}, 45^{\circ} \mathrm{C}$ for $30 \mathrm{~s}$, and $72{ }^{\circ} \mathrm{C}$ for $110 \mathrm{~s}$, with initial denaturation at $94{ }^{\circ} \mathrm{C}$ for $3 \mathrm{~min}$ and a final extension at $72{ }^{\circ} \mathrm{C}$ for $7 \mathrm{~min}$. 
We confirmed the success of amplification using electrophoresis into 1.5\% agarose gel with Tris-Borate-EDTA buffer and Invitrogen SYBR Safe DNA gel stain (Thermo Fisher Scientific, Waltham, MA, USA). We re-extracted the DNA of any samples for which amplification failed (17 individuals) using the DNeasy Blood and Tissue Kit (Qiagen, Valencia, CA, USA) and performed PCR under the same conditions. Hence, the success rates of PCR amplification were $86 \%(103 / 120)$ in the DNA extracts by PrepMan and $100 \%(17 / 17)$ in the DNA extracts by DNeasy in this study.

We purified PCR products by ethanol precipitation coupled with polyethylene glycol precipitation, or using ExoSAP-IT Express PCR Cleanup Reagents (Applied Biosystems, Foster City, CA, USA). In the precipitation method, we added 13\% PEG8000/1.6 M NaCl solution into PCR products at an equal ratio. After resting the products on ice for longer than $1 \mathrm{~h}$, we centrifuged them at $14,000 \mathrm{rpm}(17,800 \times \mathrm{g})$ and $4{ }^{\circ} \mathrm{C}$ for $60 \mathrm{~min}$ via the centrifuge. We removed the supernatant liquid and added $75 \mu \mathrm{L}$ of $70 \%$ ethanol. Then, we performed centrifugation at $14,000 \mathrm{rpm}(17,800 \times \mathrm{g})$ and $4{ }^{\circ} \mathrm{C}$ for $30 \mathrm{~min}$ via the centrifuge. We removed the supernatant liquid and dried the precipitated DNA fragments. Then, we dissolved the DNA fragments in 5-10 $\mu \mathrm{L}$ MilliQ water and sequenced the purified DNA fragments using a BigDye Terminator v3.1 Cycle Sequencing Kit (Applied Biosystems, Foster City, CA, USA) and ABI 3130 Genetic Analyzer (Applied Biosystems, Foster City, CAA, USA). We aligned the obtained nucleotide sequences using BioEdit version 7.2.5 software [22]. The obtained mitochondrial CO1 sequences were deposited in the DNA Data Bank of Japan, European Molecular Biology Laboratory, and GenBank (accession nos. LC574081-LC574320).

We compared the haplotype compositions of populations of $A$. bungii to examine the genetic differences between invaded regions in Japan. We also tested the genetic differences between populations of northern Kanto and southern Saitama where we collected many samples, using an analysis of molecular variance (AMOVA) for mitochondrial CO1 sequences based on pairwise nucleotide differences. We partitioned the total genetic variance into that between regions, among sites within regions, and within sites. Then, we evaluated the molecular variance among groups $\left(\Phi_{\mathrm{CT}}\right)$ and within groups $\left(\Phi_{\mathrm{SC}}\right)$, based on permutations among 10,000 replications.

We compared the sequences of Japanese individuals of $A$. bungii with those deposited in GenBank from the countries of origin to examine the relationship between the Japanese populations and populations from the countries of origin. We selected the following deposited sequences that overlapped with the short and long sequences of this study in more than 1000 bp in total; accession nos. MT371041 and KF737790 from China, and OK428926-OK429124 from Korea. We constructed haplotype networks based on 1170-bp sequences of mitochondrial CO1 shared between the sequences of this study and previously deposited ones. We used the pegas package [23] for $\mathrm{R}$ version 4.0.0 software [24] to construct the haplotype network and to perform the AMOVA.

\section{Results}

Seven haplotypes, designated A-G, were detected in analysed Japanese individuals of $A$. bungii, and there were fewer than $0.7 \%$ (10 bp) differences in bases among these haplotypes (Table 2). Haplotype B, which was found in northern Kanto, was consistent with a sequence deposited from China (accession no. KF737790) (Figure 3). Other deposited sequences from China and Korea (MT371041 and OK428926-OK429124) were not consistent with the sequences found in this study. 
Table 2. Nucleotide substitution sites in mitochondrial CO1 regions of Aromia bungii among the haplotypes detected in the present study. The shorter section was determined with the primer pair LCO1490 and HCO2198. The longer section was determined with the primer pair CO1-Corz and tRNA ${ }^{\text {Leu }}-\mathrm{R}$.

\begin{tabular}{|c|c|c|c|c|c|c|c|c|c|c|c|c|c|c|c|c|c|c|c|c|}
\hline \multirow{2}{*}{ Haplotype } & \multicolumn{13}{|c|}{ Position in Shorter Section } & \multicolumn{7}{|c|}{ Position in Longer Section } \\
\hline & 60 & 172 & 273 & 345 & 384 & 405 & 450 & 471 & 483 & 513 & 549 & 594 & 606 & 84 & 249 & 306 & 363 & 414 & 534 & 700 \\
\hline A & $\mathrm{A}$ & $\mathrm{C}$ & $\mathrm{T}$ & A & G & $\mathrm{T}$ & $\mathrm{C}$ & G & G & $\mathrm{T}$ & G & G & A & A & $\mathrm{T}$ & A & G & G & A & $\mathrm{T}$ \\
\hline $\mathrm{B}$ & $\bullet$ & $\bullet$ & $\bullet$ & $\bullet$ & A & $\mathrm{C}$ & $\bullet$ & A & $\bullet$ & $\mathrm{C}$ & $\bullet$ & $\bullet$ & $\bullet$ & $\bullet$ & $\bullet$ & $\bullet$ & A & $\bullet$ & G & $\bullet$ \\
\hline $\mathrm{C}$ & G & - & $\bullet$ & $\bullet$ & A & $\mathrm{C}$ & $\mathrm{T}$ & $\bullet$ & • & $\mathrm{C}$ & $\bullet$ & $\bullet$ & $\bullet$ & $\mathrm{G}$ & • & • & A & • & $\mathrm{G}$ & • \\
\hline D & • & • & $\bullet$ & $\bullet$ & $\bullet$ & • & • & • & • & • & • & $\bullet$ & $\bullet$ & • & • & • & • & $\bullet$ & $\mathrm{G}$ & $\bullet$ \\
\hline E & $\bullet$ & $\mathrm{T}$ & $\mathrm{G}$ & $\bullet$ & $\bullet$ & $\bullet$ & $\bullet$ & $\bullet$ & • & C & $\bullet$ & $\bullet$ & $\bullet$ & $\bullet$ & A & $\bullet$ & A & A & $\mathrm{G}$ & $\mathrm{C}$ \\
\hline $\mathrm{F}$ & • & • & $\bullet$ & $\bullet$ & $\bullet$ & • & • & • & • & $\mathrm{C}$ & • & $\bullet$ & $\bullet$ & • & $\bullet$ & $\mathrm{G}$ & $\bullet$ & $\bullet$ & $\mathrm{G}$ & $\bullet$ \\
\hline $\mathrm{G}$ & • & • & $\bullet$ & $\mathrm{G}$ & $\bullet$ & • & • & • & A & $\mathrm{C}$ & A & A & C & • & • & $\bullet$ & A & • & $\mathrm{G}$ & $\bullet$ \\
\hline
\end{tabular}

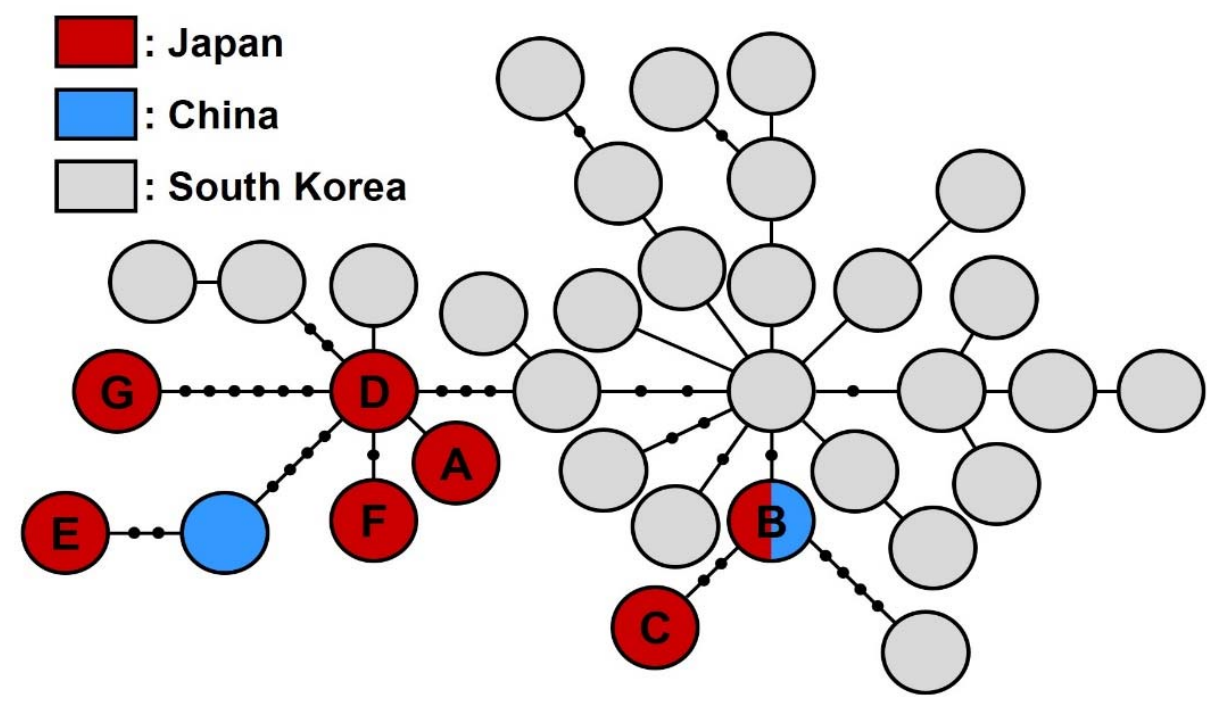

Figure 3. The haplotype network based on mitochondrial CO1 sequences (1170 bp) in Japanese, Chinese, and Korean Aromia bungii. Circles indicate haplotypes detected in this and previous studies. Black dots indicate potential haplotypes that were not collected. The seven haplotypes detected in this study were designated A-G.

Only a single haplotype was detected in populations from southern Saitama (haplotype C), western Tokyo (haplotype A), southern Tokai (haplotype D), and northern Tokushima (haplotype G) (Table 1, Figure 1). Multiple haplotypes were found in populations from northern Kanto (haplotypes A and B) and western Kansai (E and F). Two haplotypes often coexisted within populations in these regions (Table 1). The detected haplotypes were different between invaded regions, with the exception of the populations in northern Kanto and western Tokyo, which shared haplotype A. The populations of $A$. bungii were genetically different between northern Kanto and southern Saitama (Table 3). The genetic variance of Japanese $A$. bungii primarily resulted from variance between regions $(72 \%)$, and there was low genetic difference among sites within regions $(3 \%)$.

Table 3. Molecular variance analysis results for the populations of Aromia bungii in northern Kanto and southern Saitama.

\begin{tabular}{clcccc}
\hline Source of Variation & df & Sum of Squares & Variance Component & Proportion of Variance & $\boldsymbol{\Phi}$ \\
\hline Between regions & 1 & 531.9 & 14.0 & $72 \%$ & $\Phi_{\mathrm{CT}}=0.723(p<0.001)$ \\
Among sites within regions & 24 & 151.0 & 0.5 & $3 \%$ & $\Phi_{\mathrm{SC}}=0.092(p=0.071)$ \\
Within sites & 76 & 931.9 & 4.9 & $25 \%$ & \\
\hline
\end{tabular}




\section{Discussion}

We detected seven haplotypes from populations of $A$. bungii in Japan using mitochondrial CO1 sequence analyses, and one to two haplotypes were found in each region. Similar to many alien species, this low diversity in CO1 sequences suggests a bottleneck in the Japanese populations of $A$. bungii [25]. Populations of $A$. bungii could have been established by a small number of females in each region.

All the haplotypes found in Japan were not consistent with the sequences deposited from South Korea, even though the diversity of CO1 sequences of A. bungii has been investigated in detail in South Korea [26]. The CO1 sequence of haplotype B, which was found in Japan, was identical to the sequence deposited from China. These results suggest that Japanese populations of $A$. bungii have not originated from South Korea, and that at the very least, the populations in the northern Kanto region were introduced from China. However, detailed analyses of the genetic structure of populations in China, Mongolia, and Vietnam are needed to identify the area of origin of Japanese populations of A. bungii.

The detected haplotypes differed between the introduced regions, except for haplotype A, which was shared between northern Kanto and western Tokyo. Additionally, genetic differences were observed between northern Kanto and southern Saitama. These results strongly suggest that multiple introductions of $A$. bungii occurred in Japan. If populations of $A$. bungii independently established in southern Saitama, southern Tokai, western Kansai, northern Tokushima, and the other two regions, there could have been five establishment events.

The frequency of independent introductions over a period of less than 10 years in Japan could have resulted from the strong establishment ability of A. bungii, high propagule pressure, and the high susceptibility of Japanese urban habitats to this species. Females of A. bungii lay 300-500 eggs on average [27-29], which is high among cerambycid species [30]. Since males of $A$. bungii secrete sex-aggregation pheromones [31,32], mating opportunities may not be substantially decreased by a low population density. These traits of $A$. bungii suggest that they have a high ability to establish in new areas where they arrive [12,33]. The invasion pathway of $A$. bungii is thought to be via wood-packing materials used for trade [18], and the rate of imports to Japan from countries in the original A. bungii range, except for Mongolia, has recently increased (Figure 4). In particular, imports from China, where $A$. bungii is a common pest, have rapidly increased since 2000 . Therefore, the propagule pressure of $A$. bungii has likely increased dramatically in the last two decades. Additionally, the high abundance of A. bungii host plants in Japan may also elevate Japan's susceptibility to invasions. Many ornamental cherry trees are planted in urban areas throughout Japan because of the unique Japanese traditional culture of the spring cherry blossom festival (Hanami in Japanese) (Figure 5) [34,35]. Ornamental cherry trees have been damaged by $A$. bungii since the species was first detected in each of the introduced regions of Japan. Outside of Japan, in Italy, A. bungii distributes in the $250-\mathrm{km}^{2}$ area of the Campania region, and only one haplotype has been detected in this area [29]. This supports a single introduction of $A$. bungii in Italy. In Germany, the distribution of $A$. bungii has been limited to a narrow area $[1,36,37]$. Compared to these two European countries, the frequent establishment of $A$. bungii in various locations is uniquely characteristic of Japan. It seems that the combination of high propagule pressure and abundant host trees may have encouraged the frequent establishment of $A$. bungii in Japan. 


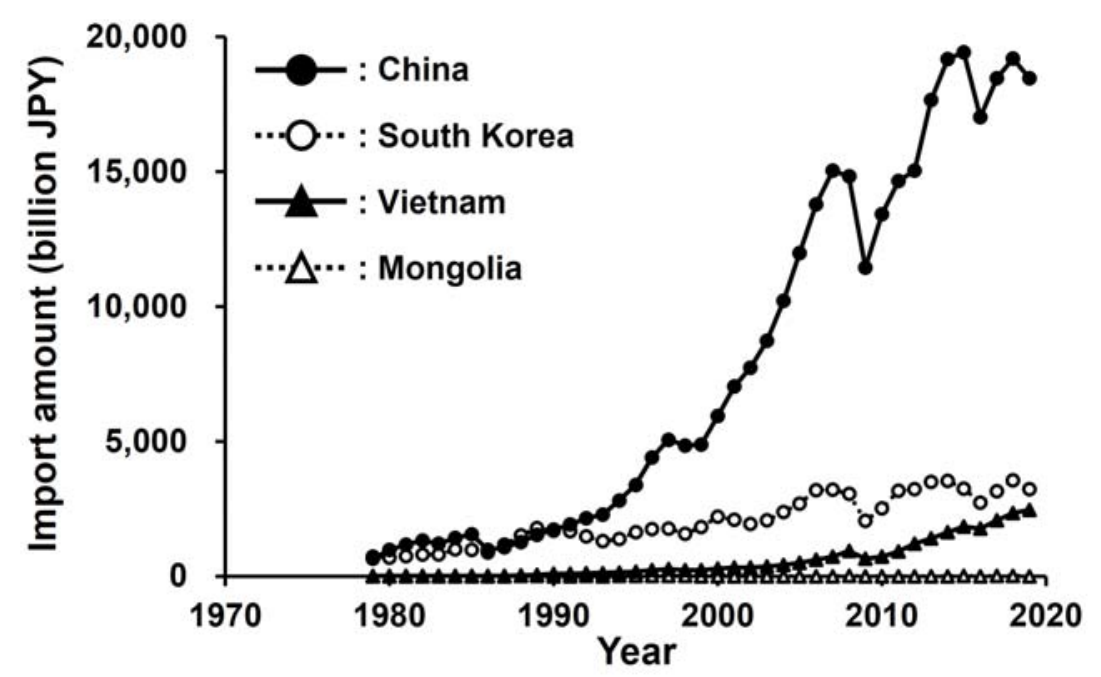

Figure 4. Import amounts from countries in the original range of Aromia bungii to Japan. This figure was drawn based on time series data obtained from Trade Statistics, Ministry of Finance Japan: https:/ / www.customs.go.jp/toukei/suii/html/time_e.htm (accessed on 20 July 2020).

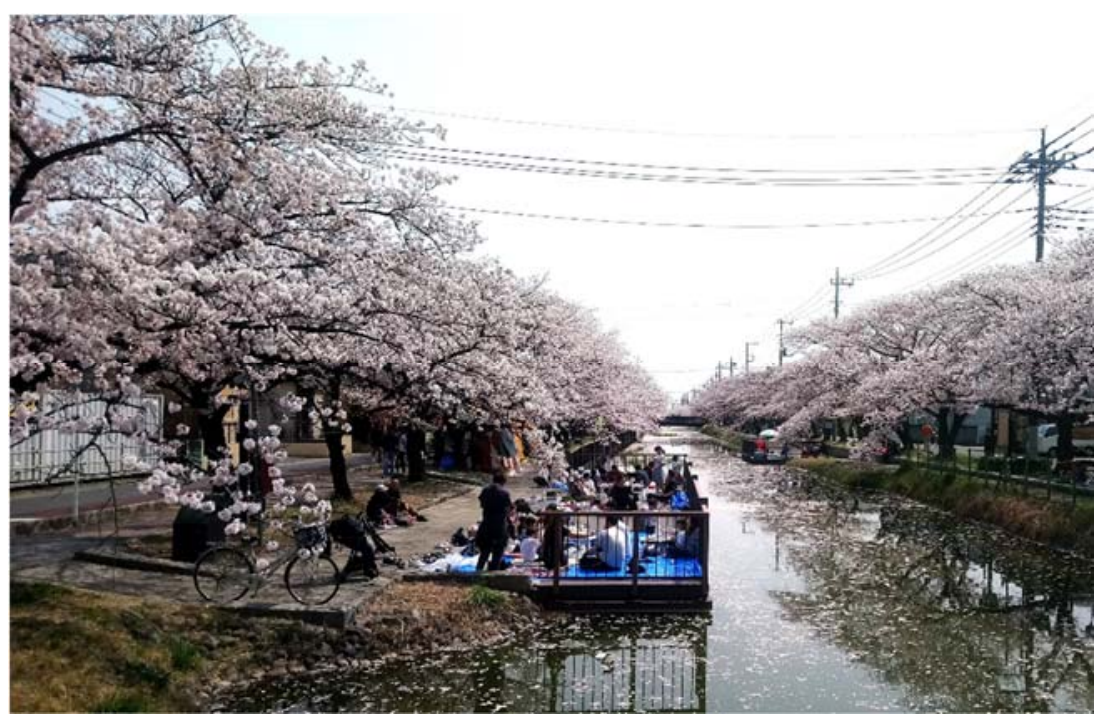

Figure 5. The cherry blossom festival along the Kasai Canal in Soka, Saitama Prefecture. Several hundred cherry trees are planted along the canal; people enjoy their time among the blossoms. This canal is the site where established Aromia bungii was first detected in southern Saitama in 2013.

One haplotype was common between northern Kanto and western Tokyo, which are 30-50 km apart. This finding could be explained by long-distance dispersal mediated by humans, which has been reported for many exotic insects (e.g., [38-40]). Additionally, an adult of $A$. bungii was observed attached to a truck in Japan [41]. Therefore, it is feasible that $A$. bungii individuals have been accidentally transported between these introduced regions by vehicles. However, it remains probable that individuals of $A$. bungii have been independently introduced into these regions from populations in their original distribution range. Further studies using more detailed DNA markers (e.g., microsatellite markers) are needed to clarify this.

We found that the $\mathrm{CO} 1$ sequences of $A$. bungii are different between non-contiguous regions in Japan, suggesting that multiple introductions of $A$. bungii have contributed to the wide distribution of this beetle, less than a decade after the detection of its establishment. Since 2007, the Japanese government has required exporting countries to treat woodpacking materials in accordance with the International Standards for Phytosanitary Measure 
No. 15 (ISPM 15) [42]. However, the ISPM 15 treatment does not kill all wood-boring insects $[43,44]$. Therefore, quarantine measures for wood-packing materials and the early detection of new invasions of $A$. bungii around cargo destinations need to be strengthened to prevent further establishments of $A$. bungii into uninvaded regions in Japan.

Supplementary Materials: The following supporting information can be downloaded at: https: / / www.mdpi.com/article/10.3390/insects13030217/s1; Table S1: the information of sampling sites and collected individuals, their haplotypes, and GenBank accession numbers.

Author Contributions: Conceptualization, S.T. and E.S.-K.; methodology, S.T. and E.S.-K.; validation, S.T. and E.S.-K.; formal analysis, S.T.; investigation, S.T.; resources, S.T. and E.S.-K.; data curation, S.T.; writing—original draft preparation, S.T;; writing—review and editing, S.T. and E.S.-K.; visualization, S.T. and E.S.-K.; supervision, E.S.-K.; project administration, E.S.-K.; funding acquisition, E.S.-K. All authors have read and agreed to the published version of the manuscript.

Funding: This study was funded by the Bio-Oriented Technology Research Advancement Institution, the National Agriculture and Food Research Organization (NARO; Research Program on the Development of Innovative Technology, no. 30023C), and the Japan Society for the Promotion of Science (JSPS; Grant-in-Aid for Scientific Research no. 15K07500).

Institutional Review Board Statement: Not applicable.

Data Availability Statement: All data analyzed in this study are indicated in this article and the Supplementary Materials, or have been deposited into the DNA Data Bank of Japan, European Molecular Biology Laboratory, and GenBank. GenBank accession numbers are indicated in-text and in Table S1.

Acknowledgments: We are grateful to the following people, who provided samples and assisted in the field: T. Urano, T. Matsumoto, and E. Sunamura at the Forestry and Forest Products Research Institute; S. Kaneko and Y. Yamamoto at the Research Institute of Environment, Agriculture, and Fisheries, Osaka Prefecture; M. Kano and H. Ishii at the Ecosystem Conservation Society-Saitama; M. Fukuda, N. Haruyama, and S. Yasaka at the Tochigi Prefectural Agricultural Experiment Station; K. Iwashita at the Aichi Prefectural Forestry Research Institute; A. Nakano at the Tokushima Agriculture, Forestry, and Fisheries Technology Support Center; H. Noda at Ibaragi Prefecture, N. Toda at Meijo University, and K. Hirano. We thank the organizations and people that permitted sample collections on their land, including the municipal governments of Akiruno, Fussa, and Soka; Dokkyo University; Tone Canal Management, and the Construction Office of the Japan Water Agency, as well as anonymous landowners.

Conflicts of Interest: The authors declare no conflict of interest.

\section{References}

1. EPPO. Aromia bungii. EPPO Bull. 2015, 45, 4-8. [CrossRef]

2. Huang, B.K.; Zhao, H.Q. Aromia bungii Faldermann. In Forest Insects of China; Xiao, G., Ed.; China Forestry Press: Beijing, China, 1992; pp. 465-466. (In Chinese)

3. Shoda-Kagaya, E. Invasion of the red-necked longicorn beetle, Aromia bungii: Damages of Rosaceae trees and practical control methods. Tree For. Health 2018, 22, 68-72. (In Japanese)

4. Hougen, T.; Kitajima, H.; Katsuki, T. Growth of an alien long-horned beetle, Aromia bungii hatchlings inoculated into smart twigs of montane rosaceous tree species. For. Pests 2019, 68, 99-103. (In Japanese)

5. Special Report on Forecast of Pest Occurrence. No. 2. Available online: https://www.pref.aichi.jp/uploaded/attachment/319462 .pdf (accessed on 5 July 2020). (In Japanese)

6. Iwata, R. Aromia bungii (Coleoptera: Cerambycidae): Taxonomy, distribution, biology and eradication. For. Pests 2018, 67, 189-216. (In Japanese)

7. Tamura, S.; Shoda-Kagaya, E. The expansion of Aromia bungii in Japan. Shinrin Kagaku 2020, 89, 21-25. (In Japanese) [CrossRef]

8. Kano, M.; Nonaka, T.; Kiriyama, S.; Iwata, R. Aromia bungii (Coleoptera: Cerambycidae), an invasive cerambycid, found at Soka, Saitama Pref., Japan, infesting cherry trees, Cerasus $\times$ yedoensis "Somei-yoshino". For. Pests 2014, 63, 101-105. (In Japanese)

9. Kiriyama, S.; Iwata, R.; Shoda-Kagaya, E. Newly discovered populations of Aromia bungii (Faldermann), an invasive cerambycid infesting cherry and Japanese apricot trees in Tatebayashi, Gunma Pref., and Fussa, Tokyo Pref. Plant Prot. 2015, 69, 807-809. (In Japanese)

10. The Ecology and Control Methods of Aromia bungii. Available online: http://www.jppn.ne.jp/osaka/color/Aromia_\%0Abungii/ Aromia_bungii(H3104).pdf (accessed on 5 July 2020). (In Japanese) 
11. Nakano, A. Damage caused by the red-necked longhorn beetle, Aromia bungii in Tokushima Prefecture and control measure. Jpn. J. Pestic. Sci. 2018, 43, 12-16. (In Japanese) [CrossRef]

12. Brockerhoff, E.G.; Liebhold, A.M. Ecology of forest insect invasions. Biol. Invasions 2017, 19, 3141-3159. [CrossRef]

13. Cognato, A.I.; Hoebeke, E.R.; Kajimura, H.; Smith, S.M. History of the exotic ambrosia beetles Euwallacea interjectus and Euwallacea validus (Coleoptera: Curculionidae: Xyleborini) in the United States. J. Econ. Entomol. 2015, 108, 1129-1135. [CrossRef]

14. Bittner, T.D.; Hajek, A.E.; Haavik, L.; Allison, J.; Nahrung, H. Multiple introductions of Sirex noctilio (Hymenoptera: Siricidae) in northeastern North America based on microsatellite genotypes, and implications for biological control. Biol. Invasions 2017, 19, 1431-1447. [CrossRef]

15. Javal, M.; Lombaert, E.; Tsykun, T.; Courtin, C.; Kerdelhué, C.; Prospero, S.; Roques, A.; Roux, G. Deciphering the worldwide invasion of the Asian long-horned beetle: A recurrent invasion process from the native area together with a bridgehead effect. Mol. Ecol. 2019, 28, 951-967. [CrossRef] [PubMed]

16. Javal, M.; Roques, A.; Haran, J.; Hérard, F.; Keena, M.; Roux, G. Complex invasion history of the Asian long-horned beetle: Fifteen years after first detection in Europe. J. Pest Sci. 2019, 92, 173-187. [CrossRef]

17. Wu, Y.; Krishnankutty, S.M.; Vieira, K.A.; Wang, B.; Nadel, H.; Myers, S.W.; Ray, A.M. Invasion of Trichoferus campestris (Coleoptera: Cerambycidae) into the United States characterized by high levels of genetic diversity and recurrent introductions. Biol. Invasions 2020, 22, 1309-1323. [CrossRef]

18. Pest Risk Analysis for Aromia bungii. Available online: http://www.eppo.int/QUARANTINE/Pest_Risk_Analysis/PRA_intro. htm (accessed on 5 July 2020).

19. Folmer, O.; Black, M.; Hoeh, W.; Lutz, R.; Vrijenhoek, R. DNA primers for amplification of mitochondrial cytochrome c oxidase subunit I from diverse metazoan invertebrates. Mol. Mar. Biol. Biotechnol. 1994, 3, 294-299. [CrossRef] [PubMed]

20. Roehrdanz, R.L. An improved primer for PCR amplification of mitochondrial DNA in a variety of insect species. Insect Mol. Biol. 1993, 2, 89-91. [CrossRef]

21. Kawai, M.; Shoda-Kagaya, E.; Maehara, T.; Zhou, Z.; Lian, C.; Iwata, R.; Yamane, A.; Hogetsu, T. Genetic structure of pine sawyer Monochamus alternatus (Coleoptera: Cerambycidae) populations in Northeast Asia: Consequences of the spread of pine wilt disease. Environ. Entomol. 2006, 35, 569-579. [CrossRef]

22. Hall, T.A. BioEdit: A user-friendly biological sequence alignment editor and analysis program fro Windows 95/98/NT. Nucleic Acids Symp. Ser. 1999, 41, 95-98.

23. Paradis, E. Pegas: An R package for population genetics with an integrated-modular approach. Bioinformatics 2010, 26, 419-420. [CrossRef]

24. R Core Team. R: A Language and Environment for Statistical Computing. R Foundation for Statistical Computing, Vienna, Austria. Available online: https:/ / www.r-project.org/ (accessed on 1 December 2021).

25. Dlugosch, K.M.; Parker, I.M. Founding events in species invasions: Genetic variation, adaptive evolution, and the role of multiple introductions. Mol. Ecol. 2008, 17, 431-449. [CrossRef]

26. Lee, S.; Cha, D.; Nam, Y.; Jung, J. Genetic diversity of a rising invasive pest in the native range: Population genetic structure of aromia bungii (coleoptera: Cerambycidae) in South Korea. Diversity 2021, 13, 582. [CrossRef]

27. Hu, C.; Ding, Y.; Sun, K. Research advances of Aromia bungii in China. Agric. Technol. 2007, 27, 63-67. (In Chinese)

28. Urano, T. Reproductive biology of Aromia bungii (Faldermann) (Coleoptera: Cerambycidae) adults emerged from infested trunks of Cerasus yedoensis "Somei-Yoshino". For. Pests 2018, 67, 230-236. (In Japanese)

29. Russo, E.; Nugnes, F.; Vicinanza, F.; Garonna, A.P.; Bernardo, U. Biological and molecular characterization of Aromia bungii (Faldermann, 1835) (Coleoptera: Cerambycidae), an emerging pest of stone fruits in Europe. Sci. Rep. 2020, 10, 7112. [CrossRef] [PubMed]

30. Haack, R.A.; Keena, M.A.; Eyre, D. Life history and population dynamics of cerambycids. In Cerambycidae of the World: Biology and Pest Management; Wang, Q., Ed.; CRC Press: Boca Raton, FL, USA, 2017; pp. 71-103, ISBN 9781315313245.

31. Fukaya, M.; Kiriyama, S.; Yasui, H. Mate-location flight of the red-necked longicorn beetle, Aromia bungii (Coleoptera: Cerambycidae): An invasive pest lethal to Rosaceae trees. Appl. Entomol. Zool. 2017, 52, 559-565. [CrossRef]

32. Xu, T.; Yasui, H.; Teale, S.A.; Fujiwara-Tsujii, N.; Wickham, J.D.; Fukaya, M.; Hansen, L.; Kiriyama, S.; Hao, D.; Nakano, A.; et al. Identification of a male-produced sex-aggregation pheromone for a highly invasive cerambycid beetle. Aromia Bungii. Sci. Rep. 2017, 7, 1-7. [CrossRef]

33. Emiljanowicz, L.M.; Hager, H.A.; Newman, J.A. Traits related to biological invasion: A note on the applicability of risk assessment tools across taxa. NeoBiota 2017, 32, 31-64. [CrossRef]

34. Primack, R.; Higuchi, H. Climate change and cherry tree blossom festivals in Japan. Arnoldia 2007, 65, 14-22.

35. Sakurai, R.; Jacobson, S.K.; Kobori, H.; Primack, R.; Oka, K.; Komatsu, N.; Machida, R. Culture and climate change: Japanese cherry blossom festivals and stakeholders' knowledge and attitudes about global climate change. Biol. Conserv. 2011, 144, 654-658. [CrossRef]

36. Hörren, T. A further proof of the Asian redneck long-horned beetle Aromia bungii (Faldermann, 1835) in Germany (Coleoptera: Cerambycidae, Cerambycinae). Entomol. Zeitschrift 2016, 126, 205-207. (In Germany)

37. EFSA; de la Peña, E.; Schrader, G.; Vos, S. Pest survey card on Aromia bungii. EFSA Support. Publ. 2019, 2019, EN-17. [CrossRef]

38. Liebhold, A.M.; Halverson, J.A.; Elmes, G.A. Gypsy moth invasion in North America: A quantitative analysis. J. Biogeogr. 1992, 19, 513-520. [CrossRef] 
39. Muirhead, J.R.; Leung, B.; Van Overdijk, C.; Kelly, D.W.; Nandakumar, K.; Marchant, K.R.; MacIsaac, H.J. Modelling local and long-distance dispersal of invasive emerald ash borer Agrilus planipennis (Coleoptera) in North America. Divers. Distrib. 2006, 12, 71-79. [CrossRef]

40. Robinet, C.; Imbert, C.E.; Rousselet, J.; Sauvard, D.; Garcia, J.; Goussard, F.; Roques, A. Human-mediated long-distance jumps of the pine processionary moth in Europe. Biol. Invasions 2012, 14, 1557-1569. [CrossRef]

41. Kinuura, H.; Shirotsuka, K.; Yamamoto, Y.; Tokoro, M.; Shoda-Kagaya, E. Invasion of the red-necked longicorn beetle, Aromia bungii in Kansai region of Japan. For. Pests 2018, 67, 221-223. (In Japanese)

42. MAFF Notification No.1352, for Amendment of Import Plant Quarantine Regulation (MAF Notification No. 206, 1950). Available online: http:/ / www.pps.go.jp/english/woodpack/import/Implementation_of_ISPM_No15_E2.pdf (accessed on 27 July 2020).

43. Zahid, M.I.; Grgurinovic, C.A.; Walsh, D.J. Quarantine risks associated with solid wood packaging materials receiving ISPM 15 treatments. Aust. For. 2008, 71, 287-293. [CrossRef]

44. Haack, R.A.; Britton, K.O.; Brockerhoff, E.G.; Cavey, J.F.; Garrett, L.J.; Kimberley, M.; Lowenstein, F.; Nuding, A.; Olson, L.J.; Turner, J.; et al. Effectiveness of the international phytosanitary standard ISPM No. 15 on reducing wood borer infestation rates in wood packaging material entering the United States. PLoS ONE 2014, 9, e96611. [CrossRef] 